\title{
Assessment of demand, supply and equilibrium price on the deposit market of Ukraine
}

\author{
Serhiy Lieonov \\ Dr., Professor, Department of Finance, Banking and Insurance, Sumy State University, Ukraine
}

Iryna Didenko

Assistant, Department of Finance, Banking and Insurance, Sumy State University, Ukraine

C The Authors, 2017. This article is published with open access at ARMG Publishing.

\begin{abstract}
The paper evaluates the process of modeling of equilibrium price on the deposit market of Ukraine in the period 2005-2016 by means of formalization of the functions of the market supply and demand. By assessing the credit and deposit markets around the world in the period before the crisis and the post-crisis period, we decided to use a multivariate regression analysis to study the deposit market in Ukraine. We formed an input array of 32 independent variables, through which, by means of the method of principal component analysis and correlation analysis, we obtained 7 of the most relevant variables. After that we received two specifications of the models of supply and demand, which were conferred to the same status in order to calculate equilibrium price on the deposit market of Ukraine. The obtained values of the equilibrium price (deposit rates) amounted to $7.82 \%$, which corresponds to three points of time in the studied period: the second quarter of 2007; the fourth quarter of 2010 - the first quarter of 2011 and the third quarter of 2011 - the fourth quarter of 2010. However, this balance does not reflect a stable situation on the deposit market of Ukraine, as it has a short-term nature.
\end{abstract}

Keywords: deposit, deposit market,economic conditions of the deposit market, demand on the deposit market, supply on the deposit market, equilibrium price, deposit rates.

JEL Classification: D50, G21.

\section{Introduction}

The economic conditions of the market are a system of interaction between the level of demand and supply. The conditions of the deposit market are a system of external and internal factors (economic/non-economic) and conditions of the market development, which are reflected in the ratio between the supply and demand for temporarily available financial resources, their equilibrium price, which serves as an interest rate on deposits under the conditions of competition between the subjects of this market and possible emergence of a variety of deposit risks. As the banking sector serves as a "wallet" of the entire economy, that is, most financial resources are delivered through it, its supply and demand are a reflection of inter-sectoral interaction of banks with their customers. By dividing the banking system intothe credit and deposit markets, it is necessary to consider the specifics of each in determining the market supply and demand. The division of the banking system into credit and deposit markets should consider the specificity of each in determining the market supply and demand. Traditionally, the study of issues related to the establishment of equilibrium on the banking market, as well as identification of the most relevant factors that may affect its destabilization,becomes urgent during the structural changes in the economy. The last structural shift of this kind occurred on the global scale in the form of the financial crisis of 2008-2009, which was produced directly by the credit market. Since the deposit market is a mirror reflection of the credit market, the achievementof an equilibrium state on it creates an important prerequisite for a stable development of the banking system. The goal of this paper is formalization of the impact of the key factors on the level of supply and demand and calculation of equilibrium price on the deposit market in Ukraine.

\section{Literature review}

Researchers from different countries have begun to actively explore the main factors that led to structural changes in the banking sector and the consequences they had for national economies. We will examine some of the studies devoted to the determination of factors influencing the level of supply and demand on the credit and deposit markets. 
Barno Blaes (Blaes, 2011) in his work analyzed the role of bank and non-bank factors which caused a slowdown in lending to non-financial corporations in Germany in the post-crisis period. According to the author, during the formation of supply and demand on the credit market a number of different factors are involved, which together form the basis for the formation of monetary policy, which, in turn, is important for the management of the market conditions.

For example, as one of the instruments of the monetary policy, in response to the negative credit demand and for its intensification for borrowers and creditors, a reduction of the key interest rates on credits is applied to a critical level, which could be beneficial to both parties. On the other hand, if there is a deficit of supply on the credit market, this problem can be fixed through the instruments of the monetary policy by supporting the overall liquidity of banks and by raising financial resources in the short run at high interest rates.

The study of the German credit market was conducted by using the examples of the most significant German banks, the data on which are available on the information source of the Eurosystem's Bank Lending Survey, BLS. The author tried to answer three questions:

$>$ carrying out of bank assessment of changes in the formation of credit standards for non-financial corporations of the country;

$>$ identification of the key factors that triggered these changes;

$>$ regulation of demand on the credit market in Germany.

The impact of the global financial crisis on the structure of the credit market was also investigated by Sovaho S. (Sovago, 2011), who in his work evaluated the interaction between supply and demand on the credit market in Hungary. The economic situation in Hungary, as in other European countries, worsened considerably during the crisis. This affected the volumes of crediting, the net inflow of which began to acquire negative values. Despite the fact that in 2010 the country's GDP started to grow, the volume of lending, especially of the corporate one, continued to decline. The author decided to examine the reasons for this trend and to answer the question about the causes of disruptions in the market's equilibrium - the factors that form demand or supply on the credit market.

Equally interesting is the study of assessment of supply and demand on the credit market in the works of the Japanese scientists S. Kanoh and C. Pumpaisanchai (2008). The worsening of economic situation in Japan in 2001, which was accompanied by a gradual reduction in the rate of the GDP growth over the last decade, led to various types of research to determine the real causes of this situation.

At that time the banking sector of Japan was also experiencing difficulties. A significant reduction in longterm loans during the studied period was marked as a period of credit crisis. However, no one could say what caused the adverse situation in the banking system: improper regulation of banks or their general financial situation. The paper offers a detailed analysis of the existing approaches to identification of the term "credit crunch". Researchers have different approaches to its definition. However, all of them focus on the following characteristics: reduction in the supply of all kinds of loans because of the reduced demand on the part of borrowers, including small and big companies, deterioration of the quality characteristics of borrowers and loan portfolios of banks. In other words, there is a disruption of the ratio between supply and demand on the market, which was defined as "the supply-versus-demand puzzle" in the work of A. Berger (1993).

In the work of S. Kanoh and C. Pumpaisanchai (2008) proposed an original approach based on consideration of quality indicators. A disruption of the balance on the credit market may be caused by the structural changes in demand and supply. Non-price factors related to the activity of banks and borrowers definitely play an important role in the formation of the loan portfolio. The main problem of their use in assessing the market situation is a difficulty of gathering the necessary information and its subsequent processing. The researchers obtained the required data about the qualitative aspects in the formation of supply and demand on the credit market through a survey conducted by the expert commission of Japan among the largest banks in the country. Accordingly, banks were surveyed for the assessment of supply while households and firms were surveyed to assess demand. The obtained information on the state of the credit market in the country is a valuable instrument in identifying the main problems from the perspective of its key actors. Along with the quality indicators the study also introduced the quantitative ones, which described the banking activity, the activity of households and firms as well as macroeconomic indicators of the country's development. Accordingly, during the research, qualitative characteristics were also covered, which, through the use of a special technique, were assigned quantitative characteristics. 
The next work, carried out by the American scientist A. Dick (2002), was devoted to the assessment of the market demand for deposit services in the USA. In this article the author tried to change the standard structure in choosing the services of the banking sector, considering its following features:

$>$ the choice of a certain banking product depending on the geographical peculiarities of the market (the author divides the market into statistical metropolitan and non-metropolitan areas, under the product he means the volume of dollar deposits);

$>$ market assessment should be based on the price factor and bank restrictions regarding the use of labor, operating costs and the range of products.

A short list of key variables that affect the pricing on deposits and describe the general state of the country's banking system, include: commission expenses for services, interest rate on deposits, the number of employees servicing customers at one branch of the bank, the distance between the bank's branches, the bank's age, its's size and others.

As we see, the analyzed methodologies for assessing the supply and demand are used to analyze the equilibrium state on the credit market. To use these approaches for the study of the deposit market, they must be adapted by selecting the relevant factors and the dependent variable. In addition, choosing a model it is necessary to pay attention to the specific features of the banking system, its legal provision, the availability and accessibility of the necessary information resources. Therefore, to choose the best method, which could make it possible to assess the supply and demand on the deposit market in Ukraine, it is necessary to decide what will perform the role of dependent and independent variables and to set the correct direction of their interaction.

\section{Methods}

Selecting the necessary statistical information the following resources were used: the National Bank of Ukraine, the State Statistics Service of Ukraine, the National Commission for the State Regulation of Financial Services Markets, the Ukrainian Association of Investment Business. All data cover a period of 10 years from the first quarter of 2005 till the first quarter 2016.

The assessment of the function of supply and demand on the deposit market is a complicated process. This is related to the fact that in order to conduct a quality analysis it is necessary not just to collect a large array of input data, but to properly organize and formalize the influence of each parameter on the target function. Based on our research goals, we need to find an equilibrium state on the deposit market of Ukraine. This situation is possible under the condition that market demand and supply are balanced. Thus, when modeling equilibrium prices (interest rates on deposits) on the deposit market of Ukraine, we use the regression modeling to obtain the functions of supply and demand. Then we compare the obtained functions and find an equilibrium rate on deposits. We present a formalized record for finding an equilibrium rate on deposits ( equation 1):

$\alpha_{0}+\alpha_{1} \cdot x+\alpha_{2} \cdot D_{2}+\alpha_{3} \cdot D_{3}+\ldots+\alpha_{n} \cdot D_{n}=\beta_{0}+\beta_{1} \cdot x+\beta_{2} \cdot S_{2}+\beta_{3} \cdot S_{3}+\ldots+\beta_{m} \cdot S_{m}$,

where $\alpha_{n}, \beta_{m}$ are theoretical coefficients of the regression for assessing the function of demand and supply, respectively;

$\alpha_{0}, \beta_{0}$ - free members, which determine the value of demand and supply, respectively, under the condition that the values of independent variables equal to 0 ;

$D_{n}, S_{m}$ - values of independent variables that affect the value of demand and supply, respectively;

$x$ - equilibrium price (interest rate on deposits) on the deposit market;

$n, m$ - the number of independent variables involved in assessing demand and supply on the deposit market of Ukraine respectively.

To designate the variable of demand $(D)$ on the deposit market, we used a deposit portfolio, which consists of the funds of physical and legal persons. Explanatory variables, that is, those that affect the formation of demand on the deposit market of Ukraine, are presented in Table A. Another element of the deposit market's environment in Ukraine is market supply $S^{d}$. First of all, we define the dependent variable that reflects the level of supply on the deposit market of Ukraine. Since banks attract temporarily free financial resources of 
the market participants, we will consider them as savings of the population and business entities. The savings of people are a sum of non-financial savings and an increase in financial assets of the population.

The savings of business entities are more difficult to assess because of the lack of disclosure of their statistical information. We assume that as savings of business entities we can consider the sum of the following indicators:

$>$ cash resources of business entities;

$>$ undistributed profits of business entities;

$>$ current assets in the inventory holdings;

$>$ bank deposits of insurers;

$>$ assets of pawnshops;

$>$ assets of credit unions;

$>$ assets of mutual funds;

$>$ assets of private pension funds;

$>$ assets of other financial institutions.

Of course, we cannot be absolutely certain that all of the above-mentioned indicators are redistributed to the deposit market in the form of bank deposits, however, they can be considered as a basis for this. The same applies to the demand on the deposit market: it is necessary to identify indicators, which would be used as independent variables in assessing the offer $S^{d}$ and presented in Appendix B.

By using the principal components analysis and correlation analysis we selected seven of the most relevant factors that affect the function of supply and demand on the deposit market in Ukraine: the weighted average cost of time deposits Dep_rate (the price on the deposit market, which is a common factor for the functions of supply and demand), the discount rate of the National Bank of Ukraine Disc_rate, the standard of the necessary reservation of long-term deposits Res_long, consumer price index CPI, the average life expectancy Life_durat; the tax on the interest from deposits, Dep_tax and the level of employment, Employ.

\section{Results}

We have already determined that supply and demand on the deposit market of Ukraine depend on seven independent factors, while one factor (market price) is common to both functions. After the selection of the best specifications to reflect the structure of relationships between the variables two models were obtained (2-3).

$$
\begin{aligned}
& D^{d}=146372.1+17954.1 \cdot \text { Dep_rate }-49722.24 \cdot \operatorname{Re} s_{-} \text {long }+ \\
& +14422.86 \cdot \text { Disc_rate }+3.48 e^{-14} \cdot \exp (C P I) . \\
& S^{d}=-9004898+18613.21 \cdot \text { Dep_rate }+44999.38 \cdot \text { Life_durat }- \\
& -4310.705 \cdot \text { Dep_tax }+104871 \cdot \text { Employ, }
\end{aligned}
$$

where $\exp (C P I)$ - exponent from variable $C P I$.

Test results of the model's parameters regarding their statistical significance and the model's general quality are presented in Annex C.

Changes in demand on the deposit market are directly dependent on the changes in the weighted average cost of time deposits Dep_rate, the discount rate of the National Bank of Ukraine Disc_rate and the consumer price index CPI. At the same time, with an increase in the weighted average cost of time deposits by one unit the demand on the deposit market will grow by 17954,1 units, and with an increase in the NBU's discount rate - by 14422.86 units. The impact of the consumer price index on the deposit market's demand is insignificant. Regarding the impact of the standard of the necessary reservation of long-term deposits Res_long on effective variable $D^{d}$, we have a situation when an increase of the standard by one unit leads to the reduction in demand by 49722.24 units. In the event when the values of all independent variables used in the regression model are equal to 0 , the demand on the deposit market of Ukraine will be 146372.1 million UAH.

In model (3), the change in demand on the deposit market is directly dependent on changes in the weighted average cost of time deposits Dep_rate, the average life expectancy Life_durat and the level of employment, Employ. With an increase in the value of the weighted average cost of time deposits by one unit the level of supply on the deposit market will grow by 18613.21 units. An increase in life expectancy by one unit leads to 
the growth of supply by 44999.38 units, and the level of employment - by 104871 . At the same time, the model has one variable, a change of which leads to the reduction of supply on the deposit market. This variable is the tax on the interest from deposits Dep_tax. An increase in this type of tax would reduce market supply by 4310.705 units. Furthermore, assuming that all independent variables in the regression model (3) equal to 0 , the level of supply would assume a negative value - 9004894 units. In other words, the savings of the population and business entities, which determine the level of supply on the deposit market of Ukraine, will be fully exhausted and become costs.

Variable Employ has the strongest influence on the level of supply. This result is logical because the more active the labor activity of the population, the more it will save. On the other hand, a high level of employment helps increase production in all areas, the results of which in the form of financial resources will have an impact on the deposit market and ensure its supply.

It is possible to achieve equilibrium on the market by equating the functions of market supply and demand in relation to changes in deposit prices (the weighted average cost of time deposits Dep_rate).

$$
D^{d}(x)=S^{d}(x)
$$

where $x$ is the weighted average cost of time deposits Dep_rate.

Since the ultimate goal is to achieve equilibrium price on deposits, it is necessary to change independent variables in models (2-3), which are used in assessment (Life_durat, Dep_tax, Employ, Disc_rate, Res_long, $C P I$ ) into their average values, retaining the independent variable Dep_rate (equation 5) as unknown component.

$$
\begin{aligned}
& 146372.1+17954.1 \cdot x-49722.24 \cdot 1.22+14422.86 \cdot 11.022+3.48 e^{-14} \cdot e^{11.72}= \\
& =-9004898+18613.21 \cdot x+44999.38 \cdot 69.9-4310.705 \cdot 2.51+104871 \cdot 58.26
\end{aligned}
$$

Equation 5 showed that equilibrium price on the deposit market of Ukraine in the period 2005- 2016 was $7.82 \%$. Figure 1 shows that during the studied period the market was three times in the state of short-term equilibrium: the second quarter of 2007; the fourth quarter of 2010 - the first quarter of 2011 and the third quarter of 2011 - the fourth quarter of 2010.

The periods of deposit rate equilibrium as well as the optimum values of supply and demand on the deposit market are presented in Table 4 in Appendix. In setting the determined equilibrium deposit rate, the real values of the market supply and demand (the fourth and the fifth lines in Appendix), unlike the corresponding modeled values, are not balanced. If we analyze the dynamics of the real values of supply and demand during the studied period, we see that the value of the deposit market's supply is much higher than its demand. In addition, the rate of changes of the real values of supply and demand is much faster than in the modeled ones. This difference is caused by the presence of a lag, the duration of which is 2 quarters between the values of supply and demand that was also found during the study of the deposit market's conditions. This situation is explained by the influence of qualitative indicators, which are invariably present during the formation of the deposit market's conditions, but which were not taken into consideration in the model's building. In spite of this, we can argue that the obtained results of the equilibrium interest rate on deposits are correct.

\section{Conclusions and Discussion}

We have obtained two models to assess supply and demand on the deposit market in Ukraine. In assessing the supply and demand we selected an array of input data consisting of 32 factor indicators that directly or indirectly influenced the situation on the deposit market of Ukraine. As a result of the conducted factor analysis and correlation analysis only seven independent variables remained (the weighted average cost of time deposits, the discount rate of the National Bank of Ukraine, the standard of the necessary reservation of long-term deposits, consumer price index CPI, the average life expectancy, the tax on the interest from deposits, the level of employment), which became the basis of regression models 2 and 3 . The price of deposits or the weighted average cost of time deposits is an element that acts as a coherent component in assessing the conditions of the deposit market. As an independent variable, this indicator is present in both models. It is needed in order to combine the functions of supply and demand, to determine the equilibrium state on the market and the optimum average interest rate on deposits. The calculated value of the equilibrium rate on deposits and the frequency of its occurrence indicate that the deposit market in Ukraine over the last decade was in unstable 
condition. In fact, the market was balanced only once in the second quarter of 2007, as the other two periods, when the level of interest rates reached calculated marks, were short-term ones, which makes it impossible to talk about the balance of the market conditions.

\section{Recommendations}

During the study of the conditions of the deposit market in Ukraine we formalized a system of relationships between the key factors and examined the market equilibrium. It is important that this analysis was conducted for all banks in the banking system of Ukraine and during a lengthy period of time (10 years). The research can be improved by extending the time range or through its detailing (monthly), more precise specification of dependent variables that describe the level of supply and demand on the deposit market, the selection of other independent variables with the inclusion, for example, of the market's qualitative characteristics. A calculation of predictive values of supply and demand with further possibilities to determine an equilibrium state can become the basis for further research. Since the deposit market is an opposite component in the banking sector regarding the credit market, it would be interesting to use the proposed method in order to investigate the situation on the credit market and determine its equilibrium state, thus conducting a comprehensive analysis of the entire banking system of Ukraine.

\section{References}

1. Berger, A.N., Udell, G.F. (1994). Did Risk-Based Capital Allocate Bank Credit and Cause a"Credit Crunch"in the United States? Journal of Money, Credit and Banking, 26(3), 585-633.

2. Blaes, Barno (2011). Bank-related loan supply factors during the crisis: an analysis based on the German bank lending survey. Deutsche Bundesbank, Discussion Paper, Series 1: Economic Studies, No. 31, p. 48.

3. Dick, A. (2002). Astrid Demand Estimation and Consumer Welfare in the Banking Industry, November 6.

4. Kanoh, S., Chakkrit Pumpaisanchai (2006). Listening to the Market: Estimating Credit Demand and Supply from Survey Data. Institute of Economic Research Hitotsubashi University, February, 37 p.

5. Sovago, S. (2011). Identifying supply and demand in the Hungarian corporate loan market. MNB Occasional papers, No. 94, $28 \mathrm{p}$.

6. The banking system of Ukraine: results of 9 months of 2011 and key development trends. National rating agency "Rurik". Retrieved from http://rurik.com.ua/documents/research/bank_system_tendency_ \%D0\%86\%D0\%86\%D0\%86_\%D0\%BAv_2011_ukr.pdf. Accessed August 25, 2016.

7. The data financial statements of banks Ukraine. Official website of the National Bank of Ukraine. Retrieved from http://www.bank.gov.ua/control/uk/publish/category?cat id=64097. Accessed August 25, 2016.

8. Deposits of depository corporations (excluding National Bank of Ukraine). Official website of the National bank of Ukraine. Retrieved from http://www.bank.gov.ua/control/uk/publish/ article?art_id=24338412\&cat_id=12063884. Accessed August 26, 2016.

9. State Statistics Service of Ukraine. Official website of the State Statistics Service of Ukraine. Retrieved from http://www.ukrstat.gov.ua/. Accessed August 26, 2016.

10. The National Commission for State Regulation of Financial Services Markets. Official website of The National Commission for State Regulation of Financial Services Markets. Retrieved from http://nfp.gov.ua/. Accessed August 25, 2016.

11. Main indicators of banks in Ukraine. Official website of the National Bank of Ukraine. Retrieved from https://bank.gov.ua/control/uk/publish/article?art_id=34661442\&cat_id=34798593. Accessed August 25, 2016.

12. Ukrainian Association of Investment Business. Official website of the Ukrainian Association of Investment Business. Retrieved from http://www.uaib.com.ua/about uaib/dv rokiv.html. Accessed August 25, 2016. 


\section{Appendices}

Table 1. The list of variables that affect the level of demand on the deposit market of Ukraine

\begin{tabular}{|l|l|l|}
\hline \multicolumn{1}{|c|}{ Variables } & \multicolumn{1}{|c|}{ Indicator } & Unit of measurement \\
\hline Dep_rate & $\begin{array}{l}\text { Weighted average cost of time deposits according to the statisti- } \\
\text { cal reporting of banks in Ukraine in the national currency, total }\end{array}$ & $\%$ \\
\hline Ass & Assets of banks & Thousand UAH \\
\hline Funds_of_legal_ent & Funds of legal entities & Thousand UAH \\
\hline Funds_of_indiv & Funds of individuals & Thousand UAH \\
\hline Borrow & Borrowed funds & Thousand UAH \\
\hline Call_dep & Call deposits & Million UAH \\
\hline Dep_lyear & Deposits with maturity up to 1 year & Million UAH \\
\hline Dep_l-2years & Deposits with maturity up to 1-2 years & Million UAH \\
\hline Dep_more_than_2years & Deposits with maturity more than 2 years & Million UAH \\
\hline Disc_rate & Discount rate of the National Bank of Ukraine & $\%$ \\
\hline Ref_rate & Refinancing rate (weighted average rate for all instruments) & $\%$ \\
\hline Dep_in_liab & Share of deposits in liabilities & \\
\hline Dep_fin_corp & Deposits of other financial corporations & Million UAH \\
\hline Dep_state_manag & Deposits of the general management sector & Million UAH \\
\hline Dep_nonfin & Deposits of non-financial corporations & Million UAH \\
\hline Dep_others & Deposits of other sectors of the economy & Million UAH \\
\hline Res_short & Standard of the necessary reservation of short-term deposits & $\%$ \\
\hline Res_long & Standard of the necessary reservation of long-term deposits & $\%$ \\
\hline CPI & Consumer price index & $\%$ \\
\hline Banks & Number of banks & Units \\
\hline & &
\end{tabular}

Table 2. The list of variables that affect the level of supply on the deposit market of Ukraine

\begin{tabular}{|l|l|l|}
\hline \multicolumn{1}{|c|}{ Variables } & \multicolumn{1}{|c|}{ Indicator } & \multicolumn{1}{c|}{ Unit of measurement } \\
\hline Dep_rate & $\begin{array}{l}\text { Weighted average cost of time deposits according to the statisti- } \\
\text { cal reporting of banks in Ukraine in the national currency, total }\end{array}$ & $\%$ \\
\hline Res_cap & Reserve capital & Million UAH \\
\hline Dep_tax & Tax on the interest from deposits & $\%$ \\
\hline CPI & Consumer price index & $\%$ \\
\hline GDP & Gross domestic product at current prices & Million UAH \\
\hline Costs & Consumer spending & Million UAH \\
\hline Wage & Average monthly salary & UAH \\
\hline Life_durat & Average life expectancy & Years \\
\hline Econ_growth & Rates of economic growth & $\%$ \\
\hline Taxes & $\begin{array}{l}\text { Tax burden on economic entities (the amount of corporate } \\
\text { income tax and current taxes on income, property and other } \\
\text { paid transfers) }\end{array}$ & Million UAH \\
\hline Purch & $\begin{array}{l}\text { The share of income used for the purchasing of goods and } \\
\text { services }\end{array}$ & \\
\hline Consum & Expenditures on goods and services & Million UAH \\
\hline Companies & Number of companies & Units \\
\hline Employ & Rate of employment of the population (aged 15-70) & $\%$ \\
\hline
\end{tabular}


Table 3.1. Results of the multiple regression with the changed values of the variable $\mathrm{CPI}^{*}$ (for assessing demand on the deposit market of Ukraine)

\begin{tabular}{|c|c|c|c|}
\hline Variable & Model coefficient & $t$-statistics & 1.67 \\
\hline Free term & 146372.1 & 2.17 & 0.102 \\
\hline Dep_rate & 17954.1 & 3.03 & 0.036 \\
\hline Disc_rate & 14422.86 & -4.23 & 0.004 \\
\hline Res_long & -49722.24 & 2.50 & 0.000 \\
\hline Exp $($ CPI $)$ & $3.48 \mathrm{e}^{-14}$ & 0.043 \\
\hline \multicolumn{2}{|c|}{$R^{2}=0.76$} \\
\hline \multicolumn{2}{|c|}{$F(4.40)=14.38 p<0.00000$} \\
\hline
\end{tabular}

Notes: * Statistically significant at the 0.05 level.

Table 3.2. Results of the multiple regression* (for assessing supply on the deposit market of Ukraine)

\begin{tabular}{|c|c|c|c|}
\hline Variable & Model coefficient & $t$-statistics & $p$-level \\
\hline Free term & -9004898 & -10.534 & 0.000 \\
\hline Dep_rate & 18613.21 & 3.661 & 0.001 \\
\hline Life_durat & 44999.38 & 3.648 & 0.001 \\
\hline Dep_tax & -4310.705 & -1.981 & 0.017 \\
\hline Employ & 104871 & 7.345 & 0.000 \\
\hline \multicolumn{2}{|c|}{$F(4.40)=50.561 p<0.00000$} \\
\hline
\end{tabular}

Notes: ${ }^{*}$ Statistically significant at the 0.05 level.

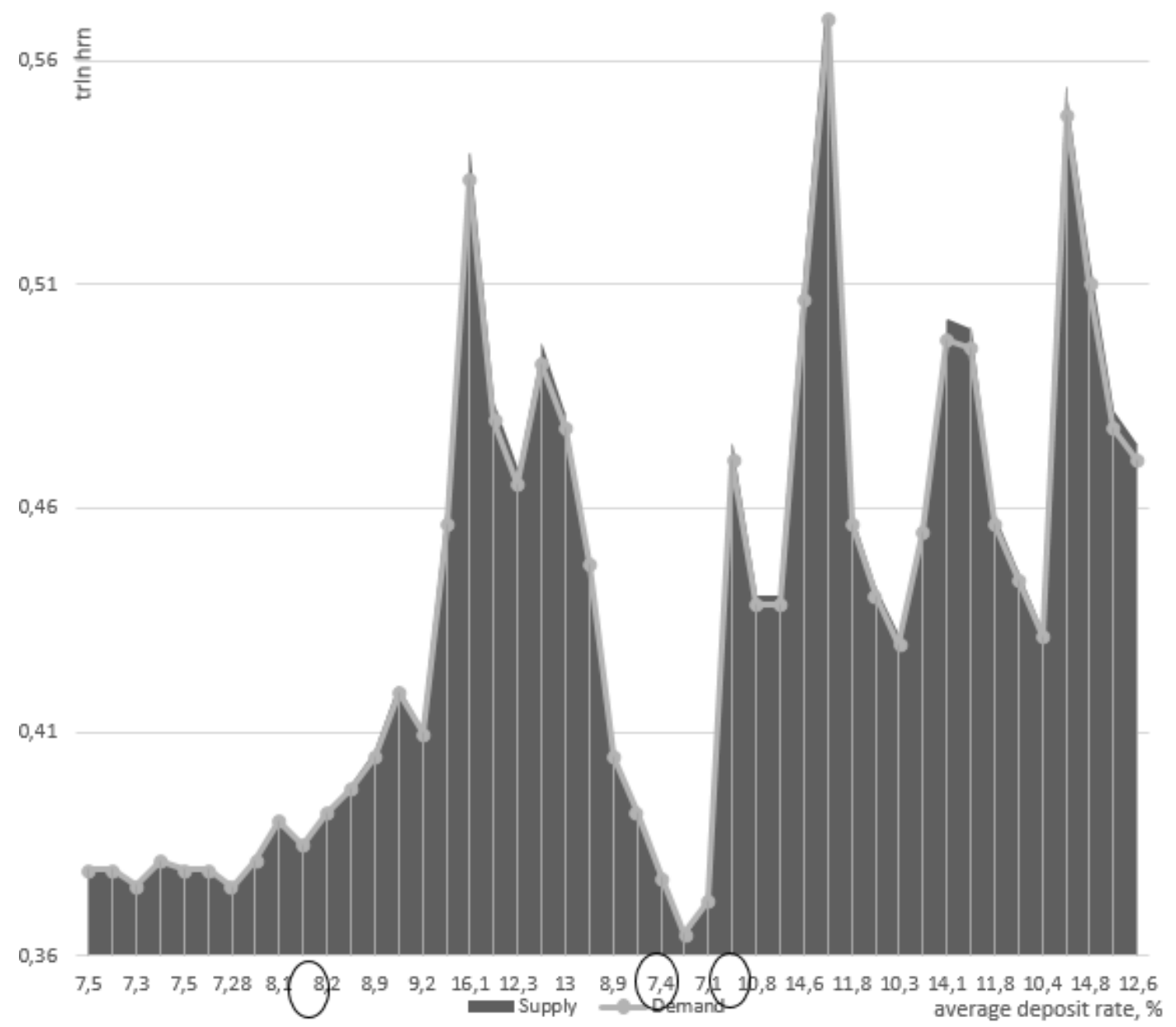

Figure 1. Dynamics of changes in the modeled functions of demand $D^{d}(x)$ and supply $S^{d}(x)$ on the deposit market of Ukraine and equilibrium prices during 2005-2016 
Appendix E. Data on equilibrium weighted average interest rate on deposits and optimum values of supply and demand on the deposit market of Ukraine

\begin{tabular}{|c|c|c|c|c|c|}
\hline Quarter & Weighted average interest rate on deposits & $D^{d_{\text {real }}}$ & $S_{\text {real }}^{d_{\text {nal }}}$ & $D_{\text {model. }}^{d}$ & $S^{d}$ model. \\
\hline 1 quarter 2005 & 7.5 & 107292.36 & 150378.27 & 379228.2 & 378729.8013 \\
\hline 2 quarter 2005 & 7.5 & 116181.33 & 163755.51 & 379228.2 & 378729.8013 \\
\hline 3 quarter 2005 & 7.3 & 128904.96 & 181067.30 & 375637.4 & 375007.1593 \\
\hline 4 quarter 2005 & 7.6 & 147094.06 & 230768.72 & 381023.6 & 380591.1223 \\
\hline 1 quarter 2006 & 7.5 & 151939.14 & 196212.02 & 379228.2 & 378729.8013 \\
\hline 2 quarter 2006 & 7.5 & 165059.61 & 212066.71 & 379228.2 & 378729.8013 \\
\hline 3 quarter 2006 & 7.28 & 183094.32 & 251087.20 & 375278.3 & 374634.8951 \\
\hline 4 quarter 2006 & 7.6 & 202192.62 & 318095.83 & 381023.6 & 380591.1223 \\
\hline 1 quarter 2007 & 8.1 & 220516.59 & 274837.12 & 390000.7 & 389897.7273 \\
\hline 2 quarter 2007 & 7.8 & 244645.14 & 310652.89 & 384614.4 & 384313.7643 \\
\hline 3 quarter 2007 & 8.2 & 282371.01 & 391126.46 & 391796.1 & 391759.0483 \\
\hline 4 quarter 2007 & 8.5 & 318389.17 & 493901.08 & 397182.3 & 397343.0113 \\
\hline 1 quarter 2008 & 8.9 & 350902.01 & 425260.51 & 404363.9 & 404788.2953 \\
\hline 2 quarter 2008 & 9.7 & 379868.06 & 481343.13 & 418727.2 & 419678.8633 \\
\hline 3 quarter 2008 & 9.2 & 404320.42 & 543012.36 & 409750.2 & 410372.2583 \\
\hline 4 quarter 2008 & 11.8 & 436726.74 & 508741.65 & 456430.8 & 458766.6043 \\
\hline 1 quarter 2009 & 16.1 & 336143.39 & 393993.08 & 533633.5 & 538803.4073 \\
\hline 2 quarter 2009 & 13.1 & 341196.73 & 391387.19 & 479771.2 & 482963.7773 \\
\hline 3 quarter 2009 & 12.3 & 350284.32 & 400732.39 & 465407.9 & 468073.2093 \\
\hline 4 quarter 2009 & 13.8 & 349635.98 & 468767.41 & 492339 & 495993.0243 \\
\hline 1 quarter 2010 & 13 & 354977.57 & 381379.44 & 477975.7 & 481102.4563 \\
\hline 2 quarter 2010 & 11.3 & 383482.60 & 420370.06 & 447453.8 & 449459.9993 \\
\hline 3 quarter 2010 & 8.9 & 416683.25 & 455880.93 & 404363.9 & 404788.2953 \\
\hline 4 quarter 2010 & 8.2 & 439446.23 & 608062.46 & 391796.1 & 391759.0483 \\
\hline 1 quarter 2011 & 7.4 & 473264.28 & 450920.08 & 377432.8 & 376868.4803 \\
\hline 2 quarter 2011 & 6.7 & 499826.74 & 472320.55 & 364864.9 & 363839.2333 \\
\hline 3 quarter 2011 & 7.1 & 506879.48 & 548728.25 & 372046.6 & 371284.5173 \\
\hline 4 quarter 2011 & 12.6 & 524908.87 & 772095.43 & 470794.1 & 473657.1723 \\
\hline 1 quarter 2012 & 10.8 & 534837.32 & 526856.46 & 438476.7 & 440153.3943 \\
\hline 2 quarter 2012 & 10.8 & 542742.66 & 529794.27 & 438476.7 & 440153.3943 \\
\hline 3 quarter 2012 & 14.6 & 562553.72 & 575041.30 & 506702.3 & 510883.5923 \\
\hline 4 quarter 2012 & 18.1 & 597631.26 & 920368.63 & 569541.7 & 576029.8273 \\
\hline 1 quarter 2013 & 11.8 & 624051.00 & 718121.66 & 456430.8 & 458766.6043 \\
\hline 2 quarter 2013 & 10.9 & 650421.15 & 688444.72 & 440272.1 & 442014.7153 \\
\hline 3 quarter 2013 & 10.3 & 678581.80 & 721534.28 & 429499.7 & 430846.7893 \\
\hline 4 quarter 2013 & 11.7 & 702914.23 & 932065.18 & 454635.4 & 456905.2833 \\
\hline 1 quarter 2014 & 14.1 & 713493.34 & 536946.77 & 497725.3 & 501576.9873 \\
\hline 2 quarter 2014 & 14 & 690632.72 & 516496.88 & 495929.8 & 499715.6663 \\
\hline 3 quarter 2014 & 11.8 & 700277.34 & 570784.45 & 456430.8 & 458766.6043 \\
\hline 4 quarter 2014 & 11.1 & 718205.96 & 293940.21 & 443863 & 445737.3573 \\
\hline 1 quarter 2015 & 10.4 & 732155.68 & 166330.18 & 431295.1 & 432708.1103 \\
\hline 2 quarter 2015 & 16.9 & 689245.12 & 318179.48 & 547996.7 & 553693.9753 \\
\hline 3 quarter 2015 & 14.8 & 687057.38 & 374385.61 & 510293.1 & 514606.2343 \\
\hline 4 quarter 2015 & 13 & 760295.39 & 275947.37 & 477975.7 & 481102.4563 \\
\hline 1 quarter 2016 & 12.6 & 806252.16 & 136285.66 & 470794.1 & 473657.1723 \\
\hline
\end{tabular}

